ISBN 978-81-936279-8-3

13th International Conference on Language, Literature, Social Sciences and Interdisciplinary Studies

(LLSSI-18)

London (UK) June 25-26, 2018

\title{
Poetry as Resistance and Recovery: An Examination of Shock in the Poetry of Wilfred Owen and American Veterans of the Iraq War
}

\author{
Kashifa Khalid \\ Lecturer, University of Central Punjab, Pakistan
}

\begin{abstract}
Humanity has been always suffering from the wars whether it's The Great World Wars or the war in Iraq. The poets who observed fighting on the front lines carved their experiences into their literary lives and used poems as a medium of opposing war. They formed their works to condemn threats directed to humanity. The soldiers who fought The World Wars and Iraq war had an intense experience and internalized the shocking moments together. The men in the war were psychologically and emotionally shattered. Those who were fortunate enough to go back to home came upon a society totally far from their promise and the magnitudes of the war caused psychological injuries. The main focus of the paper is to compare the sentiments in Owens poetry and poetry of the fighters who participated in the Iraq war. The sentiments and the psychological trauma that $W W 1$ created have the same impact on the soldiers whether belonging to the recent times or in the time of Owen. The research will inspect the war poetry of Wilfred Owen, the psychosomatic effects from which he suffered and was prominent in his poetry. American soldiers who participated in Iraq war and wrote poetry are juxtaposed with Wilfred Owen. Brian Turner American soldier who became poet articulated the psychosomatic effects of the combat and portrays the anti-war feeling similar to Wilfred Owen. The mental agony, misery and destructive settings are also depicted by Bruce lack an American fighter war poet. It will inspect that how heroic misconceptions are shattered on the front line.
\end{abstract}

Keywords: shock, psychosomatic effects, suffering, juxtaposed, combat, shattered

\section{Introduction}

War is a demonstration of demise and damage. Combats affect the warrior's life and also result in severe psychological distresses on the soldiers. Wars disturb their feelings; they affect their individuality and totally changes their mind into a topsy-turvy. Wilfred Owen, a poet of World War One participated and died in the combat. The poems of "war poets", were also called first-hand version of the cruelty. The poets were the most talented to portray the experience of those shocking years and they wrote mostly in reply to individual experiences. They were involved on the battle field. They soon understood that it's filled with dismay and this understanding affected both their thoughts. Also it affected their lyrical techniques. They had to find a method of uttering the awful facts they had experienced.

The experience of the battle field war poets was more devastating, more protracted and more penetrating than for any earlier generation of fighters. ... Men found themselves to be ambitious devices in vast, unresponsive, objective machines, snatched of willpower, ethics, and self-respect. They were sufferers of the uncultured exploitations by the nations which they assisted and so often respected. ... Most of the poets displayed no hold of power politics, the persistent burden of arms business finances and propaganda, no understanding of reasons or therapies for the combat. They uttered merely as human beings 
trapped in confusing and dreadful events. As human beings they noted their experiences and ethical reactions. They spoke of the difficulties of modern combat led by "progressive" and "cultured" nations. (Ford 135)

The soldiers abolish the hostile forces but in the end foes are human beings. Playing the game of deaths becomes a daily routine for warriors at war. They have to tolerate the grief and deaths of their fellow soldiers. These circumstances definitely have a dejected effect on soldiers. Demise is destined and it gets in the way of peaceful tranquil mind of soldiers and deprives them of their harmony of mind. The constant emotive wrangle results in severe psychological stress.

Most of the warriors grieve from post-traumatic stress disorder. The post- traumatic disorder is described as indications for example hallucinations, feelings of disinterest, bad temper and insomnia. The pain of suffering brings them mental anxiety. The mental state intensifies due to lack of proper therapeutic care and support. Such psychological sufferings are portrayed in the poems of the Wilfred Owen and the soldiers of Iraq war .They have witnessed the same circumstances and depict the antiwar emotions.

The paper will analyze war poems of Wilfred Owen, the psychosomatic effects from which he suffered and was prominent in his poems. The conditions are juxtaposed and circumstances of World War One fighters with the American fighters who participated in Iraq war. Brian Turner American fighter who expressed the psychological effects of the combat and depicts the anti-war sentiment like Wilfred Owen. It will inspect that how heroic misconceptions are shattered on the frontline. Understanding war literature is important to understand war itself. Study of "war literature" cannot be restricted to sufferers and fighters; one must also study post-war shocks depicted in literature.

Wilfred Owen and Brian Turner displays these painful symptoms through fragmented or "haunted" language that pinpoints the awful and shocking incidents. The remarkable feature of these poems, however, is that they are very cognizant of the painful condition experienced and the dialectic of pain. The poems do not calm the reader and these traumatic experiences can be felt; they also function as a way of working through the painful flashbacks so they may be resolved.

The definition of violence is to cause damage. The repercussion of damage is suffering, pain and agony. Judith Herman in her book Trauma \& Recovery: The After Shock of Ferocity, talks about the psychological suffering that is caused by the tussle between the will to neglect awful actions and the will to accept them. She describes the psychological suffering is the condition of the helplessness. In her book she discuss the segments of recovery. Another writer Gabriele Schwab in her essay "Writing against Memory and Forgetting," also discussed similar phases of recovery. In her essay she talks about the vernacular of suffering that is suggested by Herman. She is of the opinion that narrating shocking incidents demand for "telling and witnessing" in order to heal the very same shock (102). Schwab analyzes that haunted language "induces a crack inside speech to highlight silence past. Haunted lingo makes the unseen seen that unspeakable through short form, indirection and diversion, or disintegration and deformation" (108). She says that the words and way of expression does not unveil the shock directly but it is the distinctive feature of shocked people to leave hints of what has occurred in their language. The paper focuses that all the incidents in the poem whether Owen, Turner and Lack helps he narrator to speak about their repressed memories. The aim of the war poetry is not to record or protest yet it simply works as a medium of demonstrating the unspeakable memories. The poems allow the readers to understand the consequences of ferocity that are both physical and psychological. It helps to understand how ferocity once bombarded, victimizes both the oppressor and oppressed yet stays in the writings of shocked people. Poems that captures suffering and pain are different from the poems that portray violence. The poems of shock are separated from the moment of violence and focuses on the effect of shock on the memory of the individuals. The poems try to sort out and find therapeutic way through these shocking experiences. The paper explores that how the poetry of both Wilfred Owen and American soldiers show the psychological tussle to portray one's individuality. They also show modes of recovery from shocking experiences that haunt the narrators through memories. 


\section{Discussion:}

The poems work as a medium to recall the traumatic experiences so they can be revisited and resolved at the same time. Owen's poem "Dulce et Decorum Est", shows the realistic picture of the combat field and what it was really like. The poems work as a medium to recall the traumatic experiences so they can be revisited and resolved at the same time. The poems try to solve the shocking experiences by revisiting the past and it acts a medium of healing and resolving the psychological conflicts.

Brian Turner's poem "At Lowe's Home Improvement Store" also pictures the mundane incident and helps the narrator to talk about it. He recalls his shocking experiences of war that was engraved in his mind and haunted him so that he can revisit it. Brian Turner's "At Lowe's Home Improvement Center," from the volume of poetry Phantom Noise uses a fragmented method to portray the speaker's shocking experiences. The narrator in the poem talk over a moment at a home improvement store when a regular incidence - his dropping a box of nails in aisle 16-brings back a flock of memories of battle from his time in Iraq This apparently harmless incident brings back to the forefront chains of shocking experiences. Although the narrator defines the incident concretely and devoid of abstraction, there is rigidity between the language used and how the memory is contrasted with reality. By enclosing these awful memories as a recall conveyed on at a home improvement store, Turner intensifies and makes obvious how events of this emotional greatness disturb an individual long after they have passed. All the way through the poem, Turner discovers the level of emotive and psychological disharmony by making the setting of this incident unclear until the end. The narrator in this poem is clear about the occurrences that disturb him in this poem; he exposes us to the unseen, veiled shock that resists representation. There is still, fragmentation between the examples the poet narrates and the tone with which they are defined. There is a sort of abnormality about these memories - the narrator is uncertain of whether he is in the shocking moment or in a Lowe's, and there is a sort of ambiguousness of chronological and spatial reality that symbolizes the representation of this shocking memory. Telling how the shocking memory disturbs him and comes alive in a surprising and disastrous way, the narrator notes his location, "aisle 16," when he by mistake "bust a 50 pound box of double-headed nails/ open" (5). The nails then continue to fall to the ground in a cascade that prompts him of "firing pins/ from M-4s and M-16s" (5). At first, this may appear like probable clumsiness on the narrator's behalf. Though, the word "bust" indicates intentionality and the way in which it is defined seems to suggest that the narrator used a great amount of power to open the box (5). It is as if the narrator is attempting to intentionally return to these memories in an attempt to make logic of his present reality. In an interview of veteran poet Bruce Lack, he says how shocking memories are aggressive, and Lack pin-points in his early days of being home it was hard to evade thinking about the shocking memories. Lack said,

\section{"It's like how when your tongue goes back to your sore tooth over and over again, your brain will just do it and do it and do it... Perhaps your brain does it deliberately so you learn how to wall that off so you learn how to evade things that bring that back to you" (Lack's Interview).}

The bursting open of the box of nails is important less of the ordinary reality of a Lowe's home improvement store and more of a box of arms ready to be used for fighting purposes - such that when they are finished, as the narrator notes, "hundreds of bandages will not be enough" (5).These lines discusses not only to the massacre that must have happened in the actual battlefields in Iraq, but also to the emotive chaos and shock that will overcome and that cannot only be bandaged up. Herman says in Trauma and Recovery that indication of post-traumatic stress disorder is invasion; in this indication, "it is as if time stops at the time of shock" (37). It is this sign that appears to be established in this poem, as according to Herman:

The shocking moment becomes fixed in an unusual form of memory, which breakdowns naturally into consciousness, both as recollections during get up states and as disturbing nightmares during sleep. Trivial, apparently irrelevant reminders can also arouse these memories, which often reoccur with all the gaudiness and emotive force of the original incident. Thus, even usually 
harmless settings may come to feel unsafe; for the survivor can never be certain that he will not encounter some reminder of shock. (Herman 37)

Turner's poem seems to illustrate this sign of shock through its fragmented mosaic of realism and memory. Memories of Iraq nearly "spontaneously" arise in the most ordinary of places. A minor reminder-the bursting open of a box of nails - arouses an intense and emotionally powerful incident. In spite of its clarity of images and detailed portrayals, Turner's poem highlights his shocking memory through its disintegration and patching together of two different worlds. The contrast of the basic reality of a home improvement store with the drama of a battle scene highlights the narrator's tussle to find sense in regular things. This poem discovers the notion that citizen matters no longer seem to trouble and in fact seem perky associated with the battle and turmoil that surrounds the narrator. Even though the complete poem portrays how the shocking memory attacks and takes over a journey to a Lowe's such that the narrator can no longer decide whether they are in battle or back in their current reality. This plays as a mode of resolving the sufferable conflicts lingering on in his mind. In the same way the incident of the soldier that suffered from in toxic gas torments Owen and haunts him. Through the process of explaining it he is able to tell his feelings that works as healing therapy. Shocking experiences and talking about the incidents in the creative process helps the victim to recover from all the torments.

Owens poem begins with the realistic portrayal of soldiers that are exhausted in the trenches. One of the fighter is unable to fit the gas mask and he portrays the suffering of the fighter. He writes in the poem about the gas attack: "Gas! Gas! Quick boys! An ecstasy of fumbling". (1) The poet revisits the incident through the words that have been amalgamated so intensely that the reader can feel the extremity. The graphic description can also be seen in Brian Turner's poem "At Lowe's Home Improvement". He tells in the poem the repressed memory comes alive and disturbs him in the most shockingly disastrous way in a mundane setting. The setting is "aisle 16 " and he records it very carefully when by a mistake opens a box of double headed nails with a fracturing sound. The fracturing sound of the falling of the nails on the ground gives him an imagery of "firing pins/ from M-4s and M-16s" (5). Falling of the nails adds a descriptive characteristic to the poem as it added in Owen's poem. Judith Herman discusses in her book Trauma and Recovery: The Aftershock of Ferocity, about the shocking moments that become fixed in ones memory in the most unusual form which naturally transfers into conscious. Sigmund Freud also talks about the similar repressed, shocking memories that is stored in one's unconscious and haunts the victim in the form of hallucinations and dreams. The shocking moment about the soldier that he is unable to fit his gas mask is stored in the poet's mind and haunts him.

In the poem "Dulce Et Decorum Est", focusses on the white lie that was propagated by the state. He portrays the reality that it is nugatory for dying for one's state. He gives the idea that war is not epic but useless. He satirizes and contrast the notion of war as magnificent. The naïve are willing to believe the white lie and they will until they will have the first-hand experience. The reader completely understand the truth behind the white lie. The young will only understand the irony of the situation when they will witness the difference between the lives in the ditches and the white lie that have been portrayed at home.

His purpose is clear - battle is not pleasurable and games with magnificence bestowed upon the conquerors at the end, it is dreadful by instigating an individual to kill its own kind. He advises readers not to make light of such a subject in his last verses of the poem: "My friend, you would not tell with such high zest / To children ardent for some desperate glory, / The old Lie: Dulce et decorum est / Pro patria mori". There is no integrity and splendor in dying for your state at all; rather, it terminates the countless human potentiality, which Owen highlights with his use of the word children. Children are time and again considered as the future, and as such, to encourage combat is to take part in the demolition of Mother Nature, and the future. Owen is demanding to stop the destruction of human potentiality. (Ford206) 
It is pathetic to die at such a young age for one's nation. There is no velour in it. In the poem he makes emphasis on the atrocities that tormented him. Owen makes the readers aware of the grotesque truth. The words such as "old beggars under sacks", gives makes the reader inform that these soldiers are combat exhausted. The word 'blood-shod', gives a strikingly graphic image of the inferno of war. He is showing the intensity of the war through these graphic expressions. The fragmented mosaic of realism and reminiscence portrayed as a sign of shock can be very well seen in the poem of Brain Turner. The shocking memories of Iraq war "suddenly" arise in the most mundane places that one cannot even imagine. A small incident of "bursting of the nails" (5), takes the reader into stream of consciousness. The sound of the nails compared with the bullets sketches graphically and sensitively intense picture of the incident. Placing the gas mask in Owen's poem and rupturing sound of the nail box in Brian's poem add a pictorial and descriptive image in the readers mind as well as shows he shocking experiences that were buried and repressed deep down in their minds.

In "Disable" another poem of Owen discusses the aftereffects of war. He talks about a soldier who is now living a life after the WW1 and he compares his current life with the life of war. He discusses his past

actions as soldier and now his present life gives him nothing but a mere pity from the people. Brain also uses the same kill of comparing and associating the present with the past. In both the poems the highlight is the mundane setting and how it connects with the grotesque setting of the war. The poem "Disable" opens with the setting of a usual day in the park. A man in a wheelchair sitting quietly. He is not able to do any action as most of the people are busy in their daily activities. He is just sitting calmly and watching the activities of the people. The man has lost his legs in the war. He waits vulnerably. He listens to the cheering voices of the children which depresses him. He goes into past and becomes nostalgic. The everyday mundane activities of children brought his past in front of his eyes and he remembers that he can't walk and enjoy the activities of life. The giggling and cheering voices of the children took him to that moment of past where the streets used to become all bright due to his presence. Beautiful girls waited for him and their bright faces got more appealing due to his bright presence. He feels sorrow and remorse because due to the loss of his legs. No beautiful girl will now look at him and he will not be able to dance with a beautiful girl. They will take pity on him. He says his face was vivacious now his face has washed out due to the grief and sorrows of the war. His face has become pale. His life and the brightness of the life had been taken away from him due to the loss of his legs. He becomes nostalgic and recalls his past glorious life when he was full of life. Before losing his legs, he had been a celebrated football player. He was drinking liquor and merrymaking. He registered in the army so his popularity will grow more in women and someone also recommended that he will look handsome in the uniform. Only to get fame and it was also in vogue at that time so he joined army. He was never a patriotic person. Several people were there to say goodbye. He was worshiped as a war hero when he finally came back as a war hero there were none to celebrate his homecoming. He only saw pity now in the eyes of people. He felt pity for the loss of his body and splendidness. Old age people come to meet him and inquire him about his life an illness.

He again and again compares his life present and past life. As in the poem Brian Turner's "At Lowe's Home Improvement Store" also portrays the same feelings the present incident brings the distressful feelings of war. Mundane routine incidents brings back both the narrators to their past. Just as in "At Lowe's Home Improvement Store" the incidents of combat keep on coming. The mundane setting of Bran's store and Owen's park brings back the horrifying memories of the war and how it has affected narrators' life. The poems records their protest by showing the worthlessness of the wars. The enormous waste of one's life. Highlights the psychological as well as physical injuries it causes and how it shatters such a powerful humanizing into debris. The soldiers are trying to over the shocks by collecting and recollecting the memories and narrating their truthful stories so that they can shatter the facade that has been created by the world. The poems also highlight the changing perspectives of the people. The people who come in contact with these soldiers. They consider these soldiers to be "whole" as they have sacrificed their existence. Such soldiers showing psychological weakness makes them less welcome in the eyes of the people who used to worship them for their bravery and valor. 
"Mental Cases", by Wilfred Owen, was first conscripted at Ripon in May 1918 and reviewed at Scarborough in July. It was initially called "The deranged". 'Mental Cases' could be defined as verse of the period, as it echoed the shocks after the combat. The poem talks about the dehumanization of the soldiers due to the shocking memories. Normally the word mental case is associated with people who are not able to function normally in a society. The poem sketches a scene soldiers due to trauma and shellshock they are hospitalized in a mental hospital. The poem talk about particular conditions of the soldiers that are very visible. In the start the narrator inquire and asks questions like "Who are these?" The patients don't have any individuality and they are just recognized through the numbers that were assigned to them. They lost their identity. Owen uses the words like "these "and "they" to address them. He uses these words on purpose to show the hard reality of the war and what the war has done to them. He writes about their condition, "Drooping tongues from jaws that slob their relish//Baring teeth that leer like skulls" (3). They don't have any control over their bodies. They are sitting quietly in the dark as if they are fighting a war within an outside as well. Similarly the Brian Turner's poem "Lowe's Home Improvement Store" shows that soldiers after homecoming are never normal. Small mundane incidents can make them mental cases as portrayed by Owen. They were haunted by these memories.

Similarly in "Lowe's Home Improvement Store" the narrator was unable to live a normal life. Small mundane incidents aided him to recalls the alarming memories of the Iraq war and he was unable to live a life of a normal human being. He was haunted and hunted by the destructive incidents that were engraved in his memory and he was unable to throw them out of his life. Life of the soldiers are encircles by these awful memories and incidents. The bursting open of the box of nails is important less of the ordinary reality of a Lowe's home improvement store and more of a box of arms ready to be used for fighting purposes-such that when they are finished, as the narrator notes, "hundreds of bandages will not be enough" (5). These lines discusses not only to the massacre that must have happened in the actual battlefields in Iraq, but also to the emotive chaos and shock that will overcome and that cannot only be bandaged up. Herman says in Trauma and Recovery that indication of post-traumatic stress disorder is invasion; in this indication, "it is as if time stops at the time of shock" (37).

\section{Conclusion:}

The paper has analyzed the shocking experiences that were prominent in Wilfred Owen and Brian Tuner an American veteran of Iraq war. In most of the poems of both the poets the shocking memories haunted the soldiers. The poems highlight how shocking experiences shatters one's personality. These experiences term as invaders in the ordinary daily routine of the soldiers. Trauma and suffering is highlighted by the fragmented language. Through this fragmentation the shocking experiences comes on the surface level and the shocking experiences are disclosed that were repressed in the memory.

\section{References}

[1] Herman, Judith Lewis. Shock and Recovery. New York: Basic Books, 1992. Print.

[2] Owen, Wilfred. "Anthem for a Doomed Youth." The Poems of Wilfred Owen. ed. Jon Stallworthy. New York: Norton, 1986. Print.

[3] "Miners." The Poems of Wilfred Owen. ed. Jon Stallworthy. New York: Norton, 1986. Print

[4] “Disabled.” The Poems of Wilfred Owen. ed. Jon Stallworthy. New York: Norton, 1986. Print.

[5] “Strange Meeting." The Poems of Wilfred Owen. ed. Jon Stallworthy. New York: Norton, 1986. Print.

[6] Schwab, Gabriele. "Writing Against Memory and Forgetting." Literature and Medicine 25.1(2006): 95-121. Print. https://doi.org/10.1353/lm.2006.0026

[7] Turner, Brian. Phantom Noise. Farmington, Me.: Alice James Books, 2010. Print. 